The Journal of Animal \& Plant Sciences, 31(2): 2021, Page: 610-616

ISSN (print): 1018-7081; ISSN (online): 2309-8694

\title{
OCCURRENCE, POPULATION DEVELOPMENT, INFESTATION AND DAMAGE CAUSED BY OLIVE FLY (BACTROCERA OLEA GMEL.) (DIPTERA: TEPHRITIDAE) IN OLIVE ORCHARDS OF MARDIN PROVINCE, TURKEY
}

\author{
M. Kaplan ${ }^{1}$ and Y. Bayram ${ }^{2}$ \\ ${ }^{1}$ Siirt University, Faculty of Agriculture, Plant Protection Division, 56100, SIIIRT. \\ ${ }^{2}$ Ministry of Agriculture and Forestry, General Directorate of Food and Control, 06110, ANKARA \\ Corresponding Author Email: mehmetkaplan1971@hotmail.com
}

\begin{abstract}
This study was conducted to determine the occurrence, population growth, infestation and damage caused by Olive fly in olive orchards of Mardin province during 2016-2017. Pheremone traps, yellow sticky traps and beat sheet sampling were used to monitor population development and other parameters. It was observed that the first adults emerged at the end of July or beginning of August and the pest continued emerging until end of November. The pest occurred in $42.5 \%$ of the monitored orchards, with very low infestation (1.7-3.81\%) and damage rate (2.4\%-4.2\%). The highest damage and infestation were recorded in Derik-1 area, while the lowest damage and infestation was noted in Dara orchard. The peak population development was observed during October in all orchards. Although population development varied in different years depending on temperature and humidity, Olive fly constitutes two peaks per year. The first peak appeared in September, while the latter in October. Overall, the pest had low population pressure in the monitored orchards in Mardin province. However, September and October are very critical for producers; therefore, management strategies should be opted against the pest during these months. Since olive fruits enter maturity phases during this period, these are susceptible to oviposition by the pest. Pest population could be significantly high, unless pest controlled during September and October. Yellow sticky traps combined with pheromone traps were 2-3 times more effective than Mcphail traps combined with $2 \%$ diammonium phosphate. Therefore, yellow sticky traps combined with pheromone traps will be beneficial against the pest as an effective biotechnical control strategy.
\end{abstract}

Key words: Olive, Olive fly, Bactrocera oleae, Infestation, Occurrence, Damage, Mardin province, Turkey.

https://doi.org/10.36899/JAPS.2021.2.0249

Published online October 03,2020

\section{INTRODUCTION}

Olive is consumed as nutritious fruit and provides olive oil, which is used in cooking and as an important cosmetic material. The global olive production was 21.06 million tons during 2018. Spain, Italy, Greece, Turkey, Morocco, Egypt, Algeria, Portugal, Syria and Tunisia are the major olive producing countries of the world (FAO, 2020). Globally, Turkey is ranked fourth in terms of olive production (nearly $8.98 \%$ ) and sixth according to production area (nearly 7.94\%) (Anonymous, 2016). Mardin province, situated in Southest Anatolia Region of Turkey is among the major olive producing regions of the country. There are 274.982 fruit bearing olive trees covering an area of 1.890 ha in the province (Anonymous, 2017). Several factors directly or indirectly cause yield and quality losses in olive production. The total damage caused by these factors is estimated to be $\sim 30 \%, 15 \%$ of which is caused by insect pests (Bueno and Jones, 2002). The most common pests found in olive groves often reaching economic threshold levels are; Bactrocera oleae Gmelin (Diptera: Tephritidae), Prays oleae Bern. (Lepidoptera: Hyponomeutidae), Saissetia oleae Olivier (Hemiptera:
Coccidae), Parlatoria oleae Colv. (Homoptera: Diaspidae) and Euphyllura olivina Costa. (Hemiptera: Psyllidae), respectively (Anonymous, 2007). Olive fly is one of the major pest, which causes serious damage to live by directly feeding on fruits (Bodenheimer, 1941; İyriboz, 1968; Nizamlığlu and Gökmen, 1964; Asiltürk and Ozan, 1979; Yayla et al., 1995). Olive fly could cause $20-30 \%$ yield losses under normal conditions, while in case of any epidemic this level may reach up to $70 \%$ (Neuenschwander and Michelakis, 1978). Olive fly causes an average of $0.161 \mathrm{~g}$ weight loss per fruit, while increases the acid content in extracted oil (Çakıcı and Kaya, 1982).

Since Olive fly causes significant yield loss, it is highly important to know some basic information for the development of effective management strategies against the pest. However, rare studies have been conducted to determine the occurrence and damage of Olive fly in Mardin province. This study was carried out to determine the occurence, population development, infestation and damage caused by Olive fly in Artuklu, Dara, Derik, Nusaybin and Kiziltepe districts of Mardin province during 2016-2017. Pheremone traps, sticky traps and beat sheet sampling were used to monitor the pest. This study 
will help to determine the population development, first adult emergence, last fly occurrence in nature, peak periods, infestation, occurrrence and damage caused by Olive fly in the studied region. The data generated by this study would be helpful to devise effective management strategies against the pest in future studies.

\section{MATERIALS AND METHODS}

The study was conducted in Artuklu, Derik, Dara, Nusaybin and Kizlltepe districts of Mardin province during 2016 and 2017. The materials used in the study were olive trees, Olive fly $(B$. olea) McPhail traps, 2\% Di Ammonium Phosphate (DAP), Trecee pheromone capsules, yellow sticky traps $(15 \times 20 \mathrm{~cm})$, insect aspirator, ethyl acetate, stereo-microscope, hand lense, Petri dishes and gloves etc.

Determination of Olive fly occurrence: Forty (40) olive orchards were randomly selected in Dara, Derik, Kizlltepe and Nusaybin dsitricts of Mardin province. The trees in the orchards were monitored weekly through April to October to observe the occurerence of the pest (El-Salam et al., 2019a). The trees were monitored biweekly starting from November to onwards. When the presence of any stage of pest or its damage was confirmed in the orchard, it was listed as "infested".

Determination of population development of Olive fly: The population development studies were carried out in four (4) olive orchards in Artuklu (1 orchard), Dara (1 orchard) and Derik ( 2 orchards) districts. The population development was monitored weekly from the third week of July to the end of November (Perovic et al., 2009).
McPhail traps containing 2\% diammonium phosphate and yellow sticky traps $(20 \times 15 \mathrm{~cm})$ with pheromone capsules were hanged $1.5-2 \mathrm{~m}$ above the ground. Yellow sticky traps and the attractants in the McPhail traps were changed once a week, while pheromone capsules were changed monthly (Perović et al., 2009).

Determination of infestation and damage rate of Olive fly: The orchards (selected for occurrence determinantion) were monitored fortnightly to determine the infestation rate from July to December. Hundered (100) olive fruits were randomly collected from 10 trees in each orchard, examined carefully and the number of infested fuits were counted (Crovetti et al., 1998; ElSalam et al., 2019b). Infestation rate was computed by proportioning the number of total fruits to infested (damaged) fruits. In order to determine the damage rate in fruits, 1000 fruits were randomly selected from the harvested olives. These fruits were examined carefully and damaged fruits were counted. The damage rate was determined by proportioning total number of fruits to damaged fruits (Petachi, 1991).

\section{RESULTS}

Determination of Olive fly occurrence: The highest occurrence rate $(71.43 \%)$ was noted in Derik, while the lowest $(0 \%)$ occurrence of Olive fly was recorded in Kiziltepe. Derik, Artukulu and Dara districts were highly infested with the pest, while Nusaybin and Kiziltepe were less infested (Table 1). Olive fly was observed in 17 out of 40 olive orchards monitored; thus, the occurrence rate was $42.5 \%$ in the province (Table 1 ).

Table 1. The occurrence rate of Olive fly (Bacterocera oleae) in olive orchards of Mardin province during 2016.

\begin{tabular}{cccc}
\hline Districts & The number of monitored orchards & The number of infested orchards & Occurrence rate (\%) \\
\hline Artuklu & 8 & 3 & 37.50 \\
Dara & 10 & 3 & 30.00 \\
Derik & 14 & 10 & 71.43 \\
Nusaybin & 4 & 1 & 25.00 \\
Kiziltepe & 4 & 0 & 0.00 \\
Total & 40 & 17 & 42.50 \\
\hline
\end{tabular}

Determination of population development of Olive fly with yellow sticky traps: During 2016, the first adults were recorded on $26^{\text {th }}$ July on yellow sticky traps in Artuklu and Derik-II orchards, while three adults were observed on $2^{\text {nd }}$ August in Dara and Derik-I orchards. Two peak points occured in the monitored orchards where population development was studied. The first peak point occurred on $27^{\text {th }}$ September, while the second on $25^{\text {th }}$ October (Figure 1).

During 2017, first adults were caught on $1^{\text {st }}$ August in Artuklu and Dara orchards, while it was observed on $15^{\text {th }}$ August in Derik-I and Derik-II orchards. Two peak points were occured like in 2016. The first peak point occurred on $19^{\text {th }}$ September, while the second was on $17^{\text {th }}$ October (Figure 1).

Overal higher number of individuals/trap (23) were caught during 2017 compared to 2016 (19 individuals/traps). The population of the pest increased gradually from the beginning of the season and decline was noted after the second peak point (Figure 1). 

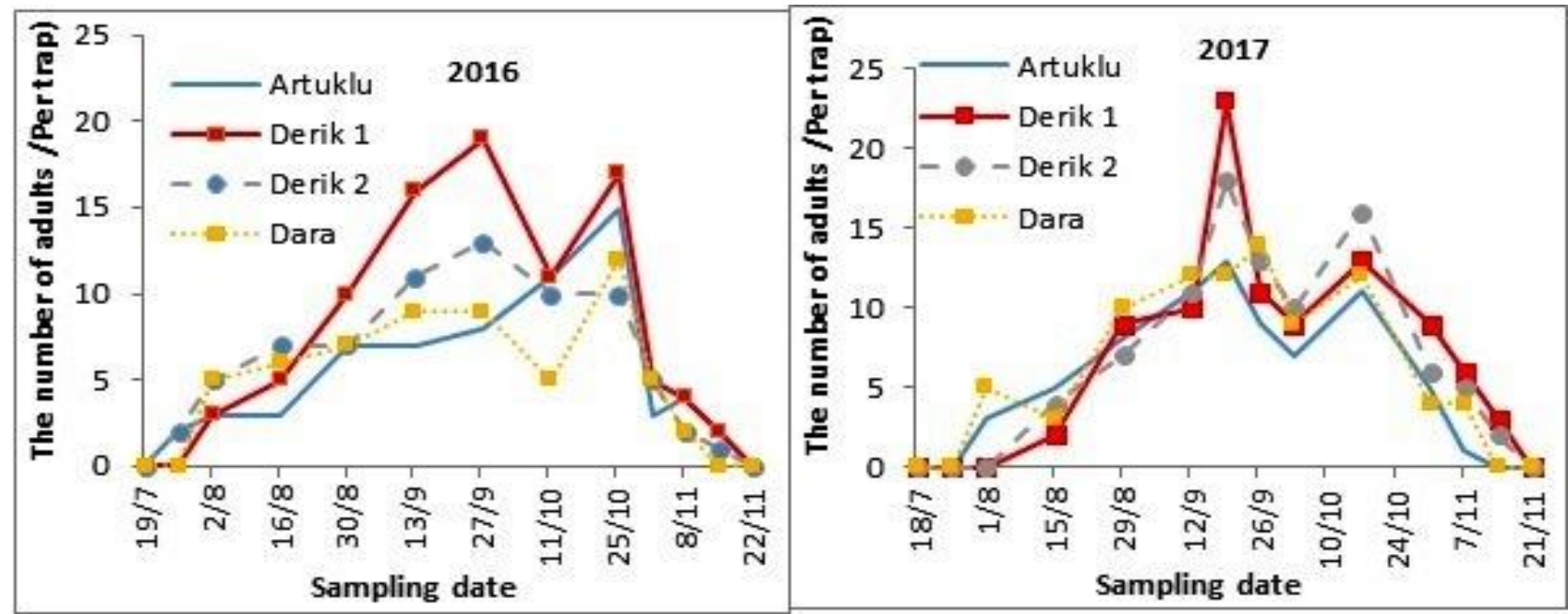

Figure 1. Population development of Olive fly on yellow sticky traps in Mardin Province during 2016 and 2017.

Determination of population development of Olive fly with McPhail type traps: During 2016, the first adults were caught in McPhail traps in the first week of August in two orchards of Derik district, while observed in the second week of August in Artuklu and Dara districts (Figure 2). Two peak points occured with the he first peak on $11^{\text {th }}$ October and second on $25^{\text {th }}$ October (Figure 2).

During 2017, the first adults were caught in McPhail traps in the second week of August in Derik-II, Artuklu and Dara districts, while they were caught in the third week of August in Derik-I orchard (Figure 2). Two peak points, same like 2016 occured during 2017. The first peak point occurred on $26^{\text {th }}$ September, while the second was on $17^{\text {th }}$ October (Figure 2).

The highest population was determined as 8 individuals/traps in 2016, while as 9 individuals/traps in 2017. At the beginning of season, population of the pest increased gradually and after second peak point population declined until third week of November and then completely deacresed. Population level was very low during both years (Figure 2).

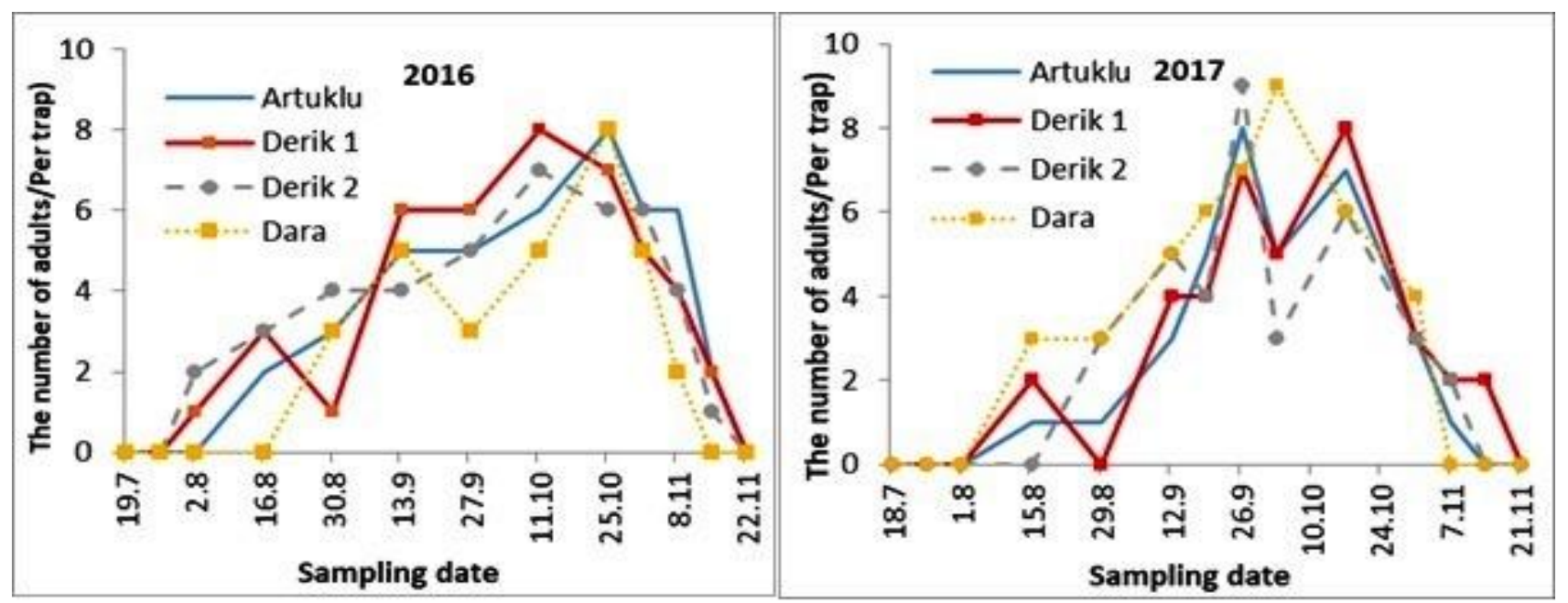

Figure 2. Population development of Olive fly in McPhail Type traps in the olive orchards of Mardin Province during 2016 and 2017.

Determination of infestation and damage rate of Olive fly: According to infestation rate studies in 2016, the first infested fruits were observed in the last week of August. Infestation rate was very low in the monitored orchards
(Table 2). The number of infested fruits started to increase in September and reached the highest level (7\%) on $11^{\text {th }}$ October in Derik-I and $18^{\text {th }}$ October in Artuklu orchards (Table 2). 
Table 2. The infestation and damage rate to olive fruits caused by Olive fly in olive orchards of Mardin province during 2016.

\begin{tabular}{|c|c|c|c|c|}
\hline \multirow[t]{2}{*}{ Date } & \multicolumn{4}{|c|}{ Infestation rate (the number of infested fruits $/ 100$ fruits) } \\
\hline & Artuklu & Derik I & Derik II & Dara \\
\hline 26.07 .2016 & 0 & - & 0 & - \\
\hline 02.08 .2016 & 0 & 0 & 0 & 0 \\
\hline 16.08 .2016 & 0 & 0 & 0 & 0 \\
\hline 30.08 .2016 & 1 & 0 & 3 & 0 \\
\hline 06.09 .2016 & 3 & 1 & 2 & 1 \\
\hline 13.09 .2016 & 3 & 2 & 1 & 0 \\
\hline 20.09 .2016 & 0 & 4 & 2 & 1 \\
\hline 27.09 .2016 & 4 & 4 & 3 & 3 \\
\hline 04.10 .2016 & 5 & 3 & 1 & 5 \\
\hline 11.10 .2016 & 5 & 7 & 5 & 5 \\
\hline 18.10 .2016 & 7 & 6 & 6 & 2 \\
\hline 25.10 .2016 & - & 6 & 5 & - \\
\hline $\begin{array}{c}\text { Average (overall total } \\
\text { / week) }\end{array}$ & $28 / 11=\mathbf{2 . 5 4}$ & $33 / 11=3.0$ & $28 / 12=\mathbf{2 . 3 3}$ & $17 / 10=1.7$ \\
\hline \multicolumn{5}{|c|}{ Damage rate (the number of damaged fruits $/ 1.000$ fruits) } \\
\hline Harvested date & $24^{\text {th }}$ October & $01^{\text {st }}$ November & $2^{\text {th }}$ October & $18^{\text {th }}$ October \\
\hline Percentage (\%) & 3.5 & 4.0 & 3.11 & 2.4 \\
\hline
\end{tabular}

According to infestation rate studies in 2017 , the first infested fruits were observed in the last week of August in Derik I and during first week of September in other orchards. While the percentage of infested fruits was very low at the beginning of the season, it increased gradually and reached the highest level in October. The highest infestation rate was recorded on $31^{\text {st }}$ September as $9 \%$ in Derik-I orchard (Table 3).

The average of infestation rate was $1.7 \%$ in Dara, $2.33 \%$ in Derik-II, $2.54 \%$ in Artuklu and $3.0 \%$ in Derik-I during 2016 (Table 2). Similarly, average of infestation rate during 2017 was $2.09 \%$ in Dara, 2.36\% in Artuklu, 3.0\% in Derik-II and 3.81\% in Derik-I (Table 3).

Table 3. The infestation and damage rate to olive fruits caused by Olive fly in olive orchards of Mardin province during 2017.

\begin{tabular}{|c|c|c|c|c|}
\hline \multirow[t]{2}{*}{ Date } & \multicolumn{4}{|c|}{ Infestation rate (the number of infested fruits $/ 100$ fruits) } \\
\hline & Artuklu & Derik I & Derik II & Dara \\
\hline 01.08 .2017 & 0 & - & - & 0 \\
\hline 15.08 .2017 & 0 & 0 & 0 & 0 \\
\hline 29.08 .2017 & 0 & 1 & 0 & 0 \\
\hline 05.09 .2017 & 3 & 0 & 2 & 0 \\
\hline 12.09 .2017 & 2 & 3 & 3 & 2 \\
\hline 19.09 .2017 & 0 & 3 & 2 & 1 \\
\hline 26.09 .2017 & 2 & 1 & 3 & 5 \\
\hline 03.10 .2017 & 4 & 3 & 0 & 4 \\
\hline 10.10 .2017 & 3 & 6 & 4 & 2 \\
\hline 17.10 .2017 & 6 & 8 & 7 & 6 \\
\hline 24.10 .2017 & 6 & 8 & 5 & 3 \\
\hline 31.10 .2017 & - & 9 & 7 & - \\
\hline Average (overall total / week) & $26 / 11=\mathbf{2 . 3 6}$ & $42 / 11=\mathbf{3 . 8 1}$ & $33 / 11=\mathbf{3 . 0}$ & $23 / 11=\mathbf{2 . 0 9}$ \\
\hline \multicolumn{5}{|c|}{ Damage rate (the number of damaged fruits /1.000 fruits) } \\
\hline Harvested date & $3^{\text {th }}$ October & $\mathbf{0 3}^{\text {rd }}$ November & $0^{\text {th }}$ November & $25^{\text {th }}$ October \\
\hline Percentage (\%) & 3.3 & 4.2 & 3.7 & 2.8 \\
\hline
\end{tabular}


According to the results of 2016 and 2017, the highest damage was noted in Derik-1, while the least damage was recorded in Dara orchard. The average damage rate was $2.4 \%$ in Dara, $3.11 \%$ in Derik-II, 3.5\% in Artuklu and 4.0\% in Derik-I during 2016 (Table 2). Similalry, average of damage rate during 2017 was $2.8 \%$ in Dara, 3.3\% in Artuklu, 3.7\% in Derik-II and 4.2\% in Derik-I (Table 3).

\section{DISCUSSION}

In earlier studies, it has been reported that Olive fly is negatively affected by high temperature and low humidity, and adult flight could be seen from mid-August to the beginning of December (Pitzalis, 1984; Daane and Jhonson, 2010; El-Salam et al., 2019b). Michelakis and Neuenschwander, (1984) reported that fruits reach to a certain maturity in September and October. During these months rainfall increases soil moisture, which favors female adults to lay eggs; resultantly, pest population is increased. Topuz, (2006) reported that Olive fly population reached peak level during October in Edremit district, Turkey. Kumral et al., (2008) reported that the pest flight started on $8^{\text {th }}$ August and adult population reached the highest level during September and November in Bursa province, Turkey. Topuz and Durmuşoğlu, (2012) reported that the adult flight started in July and pest population reached the highest level during October and November. Özpınar et al., (2014) reported that the adult flight started at the beginning of August and continued until mid December. Nonetheless, pest population reached the highest level during October in Çanakkale province, Turkey. Bozbuğa and Ulusoy, (2008) reported that pest population had 3-4 peaks in March, June-July and October-November in Adana province, Turkey. Pest population generally decreased in all orchards after this period. The results of this study are consistent with the results of previous studies. The pest flight could be seen by traps' catches from the end of July or at the beginning of August until third week of November (Perović et al., 2009). Although population development varied in different years depending on temperature and humidity, Olive fly constituted two peaks per year, first in September and the second is in October. However, Olive fly does not constitute a very high population in Mardin province. It could be said that high temperature, presence of natural enemies, regular cultural control activities and early or timely harvesting suppressed the pest population in the province. A recent study has shown that the pest could have three to five peaks in Egypt (El-Salam et al., 2019a).

Mazomenos et al., (2002) reported that traps caught more flies during spring (March and May) than in hot and dry summer months. Pheromone traps were more effective on capturing male adults in summer and autumn, while Mcphail traps were effective only in summer. Bozbuğa and Ulusoy, (2008) reported that yellow sticky traps with pheromones attractant could capture 5-6 times more Olive flies than Mcphail feeding trap. Similarly, El-Salam et al., (2019a) reported that Yellow sticky traps captured significantly more flies than McPhail traps. Topuz, (2006) reported that the number of flies caught in yellow sticky traps with pheromones was approximately 4-5 times higher than McPhail feeding traps. In our study, yellow sticky traps combined with pheromone traps found $\sim 2-3$ times more effective than Mcphail traps combined with $2 \%$ diammonium phosphate. It might be explained with the fact that pheromone traps spread pheromones to larger areas; thus, attracting pests not only from surrounding but also from remote areas as well. The results revealed that yellow sticky traps combined with pheromone will be useful for mass trapping or suppressing pest population.

The occurrence rate of Olive fly in Mardin province was $42.5 \%$ in 2016 . The most infested district was Derik, while Dara was the least affected one. Although occurrence rate was high, population development, and infestation and damage rates were very low. It can be concluded that Olive fly is present in many olive orchards, but some factors suppressed its population.

Çetin and Alaoğlu, (2005) reported that infestation rate of Olive fly in Mut district of Mersin province was very low $(0.7-3.3 \%)$. In our study, the average of infestation rate was very low in two successive years $(1.7 \%-3.0 \%$ in $2016,2.09 \%-3.81 \%$ in 2017). The highest infestation rate was $7 \%$ in 2016 , while $9 \%$ in 2017 . These results are also in accordance with previous studies conducted in different provinces of Turkey.

Olive fly is the major olive pest in the Mediterranean Basin, being responsible for high losses in olive production (Medjkouh et al., 2018a). The fly attack significantly affects the fruit weight of different olive cultivars (Medjkouh et al., 2018b). Economopoulos et al., (1982) and Michelakis, (1990) reported that in Mediterranean countries, especially in Greece and in Italy, feeding activity of Olive fly larvae caused 30\% yield losses. Patanita and Mexia, (1996) reported that product loss due to Olive fly damage is $15-30 \%$ in Portugal and weight of the damaged fruits is reduced by $55 \%$. Bento et al., (2002) reported that Olive fly caused $19 \%$ yield loss in Portugal during 1993. Topuz, (2011) reported that damage rate linearly increased with increasing population. Pala et al., (2001) reported that normally Olive fly damage is $\sim 15-30 \%$ in case of no control measures applied; however, in case of any epidemic situation this damage could reach to $70 \%$. Aysu et al., (1971) reported that Olive fly damage rate could change between $25 \%$ and $100 \%$ with no control measure in olive orchards in the Aegean region of Turkey. Bozbuğa and Ulusoy, (2008) reported that damage rate in 
Adana province was generally low with the highest damage rate of $4.3 \%$. In our study, Olive fly damage was $2.4 \%-4.0 \%$ in 2016 , while $2.8 \%-4.2 \%$ in 2017 . The highest damage occurred in Derik-1, while the least occurred in Dara orchard. However, the damage rate was generally low compared to the results of Bozbuğa and Ulusoy, (2008). Mardin province has high temperature and low humidity; therefore, pest population could not increase. However, September and October months are critical for timely application of control measures to prevent fruit damage.

Conclusion: Population development, occurrence, and infestation and damage rates of Olive fly varied during different years in Mardin province. The results could provide a general idea about the pest situation in the province. The occurrence rate was too high; however, population development, infestation and damage rates were very low. Olive fly was present in many olive orchards; however, some environmental factors suppressed its population. Thus, pest population could have not increased to significant extent. The highest infestation and damage rate were recorded in Septmeber and October, these months are critical for growers to opt management strategies. Yellow sticky traps combined with pheromone traps would be beneficial for effective biotechnical control strategy and mass trapping.

\section{REFERENCES}

Anonymous (2007). Olive Research Institute website. http://www.zae.gov.tr/bitkisagligi/z1.asp (Access date: 28.06.2018).

Anonymous (2016). FAO (Food and Agriculture Organization of United Nations). http://www.fao.org/faostat/en/?\#data/QC (Access date: 28.06.2018).

Anonymous (2017). TSI (Turkish Statistical Institute). https://biruni.tuik.gov.tr/medas/?kn=92 \&locale $=\operatorname{tr}$ (Access date: 28.06.2018).

Asıltürk, H. and İ. Ozan (1979). Investigation on Insect Fauna of Black Sea Olive. Agricultural Research Annual book, Samsun, p.72-73.

Aysu, R., C. Tokmakoğlu and N. Gökmen (1971). Studies on determination of parasites of olive fly (Dacus oleae Gmel.). Agricultural Research, Annual book, p. 54.

Bento, A., J.A. Pereira, J. Cabanas and L. Torres (2002). Bio ecology of the Olive Moth, Prays oleae (Bern.), In Tras-Os- Montes Region (Northeast of Portugal). In: 1th European Meeting of the IOBC/WPRS Study Group, Marich-China, Crete, Hellas. May 29-31, 2003. 50 p. (www. actahort.org/books).

Bodenheimer, F.S. (1941). A survey about war with insects and pests with them on agriculture and trees in Turkey. Naci Kenter, 1958, Ankara, p. 347.

Bozbuğa, R. and M.R. Ulusoy (2008). Monitoring of Olive Fruit Fly Bactrocera Oleae Gmel. (Diptera: Tephritidae) Population and Determining of Damage Rate in Adana. Çukurova University, Institute of Science and Technology Year: 2008 Volume: 17-8.

Bueno, A.M. and B. Jones (2002). Alternative methods for controlling the olive fly, Bactrocera oleae, involving semi chemicals. Use of pheromones and other semiochemicals in integrated production. IOBC wprs Bulletin 25(9):147-156.

Çakıcı, M. and M. Kaya (1982). Research on the Loss of Product Caused by Olive Fly (Dacus oleae Gmel.) and the Economic Threshold in the Aegean Region, Bornova Plant Protection Research Institute, Project Final Report A.105.024, $13 \mathrm{p}$.

Çetin, H. and Ö. Alaoğlu (2005). Investigations on the Olive Pests of Secondary Importance, Their Population Changes and Damages in Mut Distrıct (Turkey). Selçuk University, Faculty of Agriculture, J. 19 (36): (2005), 52-58.

Crovetti, A., A. Belcari and A. Raspi (1998). Plant Protection, World Olive Encyclopaedia, International Olive Oil Council, BarcelonaSpain, B, 30073-1998, p. 479.

Daane, K.M. and M.W. Johnson (2010). Olive fruit fly: managing an ancient pest in modern times. Annual review of entomology, 55, 151-169.

Economopoulos, A.P., G.E. Haniotakis and S. Michelakis (1982). Population studies on the olive fruit fly, Dacus oleae (Gmel.) (Dipt.; Tephritidae) in Western Crete. J. Appl. Entomol., 93: 463-476.

El-Salam, A.M.E., S.A. Salem, M.Y. El-Kholy, R.S. Abdel-Rahman and M.A. Abdel-Raheem (2019a). Role of the olive fly, Bactrocera oleae (Rossi) traps in integrated pest management on olive trees under climatic change conditions in Egypt. Plant Archives, 19(2), 457-461.

El-Salam, A.M.E., S.A.W. Salem, R.S. Abdel-Rahman, H.H. El-Behery, and M.A.M. Elden, (2019b). Effects of climatic changes on olive fly, Bactrocera oleae (Rossi) population dynamic with respect to the efficacy of its larval parasitoid in Egyptian olive trees. Bulletin of the National Research Centre, 43(1), 173.

FAO (2020). Food and Agriculture Organization of United Nations. http://www.fao.org/faostat/en/?\#data/QC (Access date: 20.05.2020).

İyriboz, N.Ş. (1968). Olive Pests and Diseases. Ministry of Agriculture and Forestry. General Directorate of Plant Protection and Quarantine, Research Series, İzmir, 112 p. 
Kumral, N.A., B. Kovanc1 and B. Akbudak (2008). Determination of bio ecological characteristics which will be the basis of the struggle of olive fly [Bactrocera oleae (Gmelin)] in Gemlik variety olive orchards, Uludağ University, Faculty of Agriculture J. 22(1): 31-41.

Mazomenos, B.E., A. Pantazi-Mazomenou and D. Stefonu (2002). Attract and kill of the Olive fruit fly Bactrocera oleae (Gmelin) in Greece as a part of an integrated control system. IOBC/WPRS Bulletin, 25: 137-146.

Medjkouh, L., A. Costa, A. Tamendjari, F. Bekdouche, K. Bouarroudj and M.B.P. Oliveira (2018a). Susceptibility of eight Algerian olive cultivars to Bactrocera oleae infestation a pomological and nutritional quality perspective. Phytoparasitica, 46(5), 595-605.

Medjkouh, L.,A. Tamendjari, R.C. Alves, R. Laribi and M.B.P. Oliveira (2018b). Phenolic profiles of eight olive cultivars from Algeria: Effect of Bactrocera oleae attack. Food \& function, 9(2), 890-897.

Michelakis, S. (1990). The olive fruit fly, Dacus oleae (Gmel.) in Crete, Greece. Acta Horticulturae 286: 371-374.

Michelakis, S.E. and P. Neuenschwander (1984). Bioecological data on Dacus oleae (Gmel.) for selective control in Crete, Greece. Department of Entomology, Proceedings of the CEC /FAO/ IOBC International Joint Meeting Pisa/3-6 April 94-103.

Neuenschwander, P. and S. Michelakis (1978). The infestation of Dacus oleae Gmel. (Dip.: Tephrtidae) at Harvest Time and Its Influence on Yield and Quality of Olive Oil in Crete, Z. Ang. Ent., 86, 420-433.

Nizamlığlu, K. and N. Gökmen (1964). Damaging Insects Olives in Turkey. Yenilik Basımevi, İstanbul, $160 \mathrm{p}$.

Özpınar, S., A. Özpınar, A.K. Şahin, B. Polat and B. Büyükcan (2014). The Effect of Soil Tillage on Population Density of Olive Fly (Bactrocera oleae Gmelin, 1790, Diptera: Tephritidae) in Çanakkale Province. COMU J. Agriculture Faculty, 2014: 2 (1): 83-90.

Pala, Y., A. Nogay, E. Damgacı and M. Altın (2001). Olive Integrated Combination Technical
Instruction. Ministry of Agriculture and Rural Affairs, General Directorate of Agricultural Research, Department of Plant Health Research, Ankara, 84 p.

Patanita, M.I. and A. Mexia (1996). Crop loss assessment due to Prays oleae Bern. and Bactrocera oleae Gmel in Moura region (Portugal), Preliminar results. Proc. of XX. International Congress of Entomology, Florence, Itália, 25 a 31 de Agosto, 708.

Perović, T., S. Hrnčić and D. Inđić (2009). Flight dynamics of olive fly Bactrocera oleae Gmel. (Diptera, Tephritidae) in the region of Bar. Pomologia Croatica: Glasilo Hrvatskog agronomskog društva, 15(3-4), 77-86.

Petachi, R. (1991). Dacus Oleae (Gmelin): First Results of A Study on The Infestation Dynamics in Two Biotypes From Eastern Liguria. Frust. Ent. 12, 71-90.

Pitzalis, M. (1984). Bioclimatology and insect development forecast: Degree days and phenol phases of Dacus oleae (Gmel.). Proceedings of the $\mathrm{CEC} / \mathrm{FAO} / \mathrm{IOBC}$ International Joint Meeting, Pisa, Italy/3-6 April 84-93.

Topuz, H. (2006). The Effect of Harvest Time on Bactrocera oleae (Gmelin) (Diptera: Tephritidae) Damage, Olive Oil Yield and Quality. İzmir, Master Thesis, 44p.

Topuz, H. (2011). Investigation of the Effects of Different Harvest Timing on Some Olive Varieties in Izmir and Manisa Provinces on Olive Oil Yield and Quality of Olive Harvest [Bactrocera oleae (Gmelin) (Dip.: Tephritidae)]. Ege University, Institute of Science and Technology, PhD Thesis (Unpublished), İzmir.

Topuz, H. and E. Durmuşoğlu (2012). Effects of harvest timing on infestation of Bactrocera oleae (Gmelin, 1790) (Diptera: Tephritidae), olive oil yield and quality. Turkish J. Entomology, 36(3):345-362.

Yayla, A., M. Kelten, T. Davarc1 and A. Salman (1995). Investigation of the Possibilities of Biological Control against Pests in Olive orchards of Antalya Province. Plant Protection Bulletin, Volume: 35, No: 1-2, (January-June), p. 63-91. 